\title{
ANALISIS KINERJA SUPPLY CHAIN MENGGUNAKAN MODEL SCOR (Studi Kasus pada Roti "SIP" Politeknik Negeri Jember)
}

Oleh:

\author{
M.RIZAL UMAMI *), RIDWAN ISKANDAR dan UJANG SURYADI **)
}

\begin{abstract}
ABSTRAK
Unit Pelaksana Teknis Aneka Pangan Roti "SIP" selanjutnya disingkat SIP adalah salah satu perusahaan yang bergerak di bidang pangan, dalam proses pemasaran Roti "SIP" mengalami perkembangan dan penurunan omset penjualan roti.Unit Usaha Aneka Pangan Roti "SIP"ini memiliki aktivitas supply chain yang digunakan dalam mengatur aliran barang mulai dari toko bahan-bahan roti sebagai supplier sampai kepada konsumen akhirnya. Dengan adanya penerapan konsep supply chain management diharapkan aktivitas supply chain perusahaan dapat berjalan dengan baik mulai dari produksi hingga sampai pada penjualan. Namun, pada kenyataannya ada saja permasalahan yang terjadi dalam aktivitas supply chain. Pada penelitian ini peneliti menggunakan metode SCOR, Model Supply Chain Operations Reference (SCOR) adalah salah satu metode yang dapat digunakan untuk mengukur performansi supply chain. Model SCOR membagi prosesnya menjadi 5 proses inti yaitu Plan (perencanaan), Source (pengadaan), Make (pembuatan), Deliver (penyampaian), dan Return (pengembalian). Kelima proses inti ini saling terintegrasi mulai dari supplier sampai ke konsumen akhir. Dengan menggunakan SCOR, maka akan diketahui kinerja keseluruhan fase dalam supply chain perusahaan secara terintegrasi. Hasiil penelitian ini diperoleh nilai total indeks performansi supply chain perusahaan sebesar 5.08. dalamtraffic light system nilai tersebut termasuk dalam kategori kuning yang menunjukkan bahwa perusahaan belum mencapai performa yang diharapkan.
\end{abstract}

Kata Kunci :Kinerja, Supply Chain, SCOR

\section{PENDAHULUAN}

Indonesia sebagai negara yang sedang berkembang berusaha keras memacu industrinya untuk dapat menghasilkan produk yang bermutu, agar dapat bersaing dengan produk-produk dari negara lain. Persaingan didunia bisnis menimbulkan beberapa permasalahan dan industri dituntut untuk meningkatkan Ilmu Pengetahuan dan Teknologi (Iptek).

Persaingan didunia bisnis semakin ketat, oleh karena itu permasalahan di industri semakin banyak, diantara permasalahan yang sering terjadi saat ini adalah supply chain atau rantai pasok.Banyak perusahaan belum berhasil memaksimalkan potensi Suppy chain, Supply chain merupakan hal yang sangat penting untuk diperhatikan, karena supply chain merupakan suatu proses yang sangat berpengaruh terhadap performansi perusahaan yang berhubungan dengan masalah internal maupun eksternal dari perusahaan tersebut. Saat ini persaingan yang terjadi bukan lagi antara perusahaan dengan perusahaan lainnya, tetapi antara supply chain yang satu dengan supply chain yang lainnya. Diperlukan suatu pengukuran performansi supply chain untukmengevaluasi kinerja supply chain pada perusahaan.

Pada penelitian ini peneliti menggunakan metode SCOR. Banyak model yang telah dibuat oleh akademisi, praktisi dan kolaborasi antara keduanya. Model SCOR adalah model populer di Indonesia. Ini Bahkan diindikasikan dengan jumlah yang sangat dari pelatihan yang telah dilakukan di beberapa perusahaan dalam Indonesia seperti: Charoen Pokphand, Coca-Cola, Unilever, Garuda Indonesia, dll.

Unit Usaha Aneka Pangan Roti "SIP" merupakan perusahaan yang bergerak dalam pembuatan berbagai jenis roti dan kue. Unit Usaha Aneka Pangan Roti "SIP" ini sebenarnya berasal dari Unit Usaha Jasa dan Industri (UJI) yang ada di Politeknik Negeri Jember. Tugas utama unit ini adalah memproduksi dan menggembangkan berbagai produk olahan makanan, Kemudian dilakukan produksi dan pengembangan berbagai jenis roti dan kue merk produk "SIP".Unit Usaha Aneka Pangan Roti "SIP"ini memiliki aktivitas supply chain yang digunakan dalam mengatur aliran barang mulai dari toko bahan-bahan roti sebagai supplier sampai kepada konsumen akhirnya. Dengan adanya penerapan konsep supply chain management diharapkan aktivitas supply chain perusahaan dapat berjalan dengan baik mulai dari produksi hingga sampai pada penjualan. Namun, pada kenyataannya ada saja permasalahan yang terjadi dalam aktivitas supply chain.

Perkembangan penjualan SIP dapat dilihat pada tabel 1 dibawah ini: 
M. Rizal Umami, Ridawan Iskandar dan Ujang Suryadi, Analisis Kinerja SUUPLY CHAIN Menggunakan Model Scor (Studi Kasus pada roti “SIP” Politeknik Negeri Jember)

Tabel 1. Data Perkembangan Produksi Dan Penjualan Roti “SIP” Tahun 2014

\begin{tabular}{ccccc}
\hline & & \multicolumn{3}{c}{ RotiManis } \\
\cline { 3 - 5 } No & Bulan & Produksi $^{8}$ & Terjual $^{8}$ & Kembali $^{8}$ \\
\hline 1 & Juli & 2.39 & 2.39 & - \\
2 & Agustus & 2.375 & 2.375 & - \\
3 & September & 8.181 & 7.528 & 283 \\
4 & Oktober & 9.036 & 9.325 & 591 \\
5 & November & 7.496 & 7.266 & 685 \\
6 & Desember & 6.052 & 6.018 & 386 \\
\hline
\end{tabular}

*=dalam satuan biji

Sumber: UPT Aneka Pangan 2015

Dari permasalahan produksi dan penjualan yang terjadi dapat dilihat, bahwa jumlah pengembalian roti manis SIP masih tinggi, hal ini ditunjukkan pada bulan Oktober dan Nopember 2014. Pasokan yang baik harus mempunyai retur yang rendah. Di sisi lain, Unit Usaha Aneka Pangan Roti "SIP" belum pernah melakukan pengukuran performansi supplychain. Oleh karena itu, perlu dilakukan pengukuran performansi supply chain untuk mengetahui titik terlemah kinerja perusahaan pada konsep manajemen rantai pasok. Dengan adanya pengukuran performansi supply chain ini, diharapkan perusahaan dapat mengetahui performansi kritis pada aktivitas supply chain dan melakukan perbaikan sehingga dapat meningkatkan performansi supply chain Unit Usaha Aneka Pangan Roti "SIP".

Dalam memenuhi kebutuhan pelanggan, perusahaan menerapkan konsep Supply ChainManagement (SCM) dengan menyediakan produk sesuai dengan tuntutan pasar, peran serta semua pihak sangatlah dibutuhkan, mulai dari supplier yang mengolah bahan baku dari alam menjadi komponen, pabrik yangmengubah komponen dan bahan baku menjadi produk jadi, perusahaan transportasi yang mengirimkan bahan baku dari supplier ke pabrik, serta jaringan distribusi yang akan menyampaikan produk.

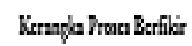

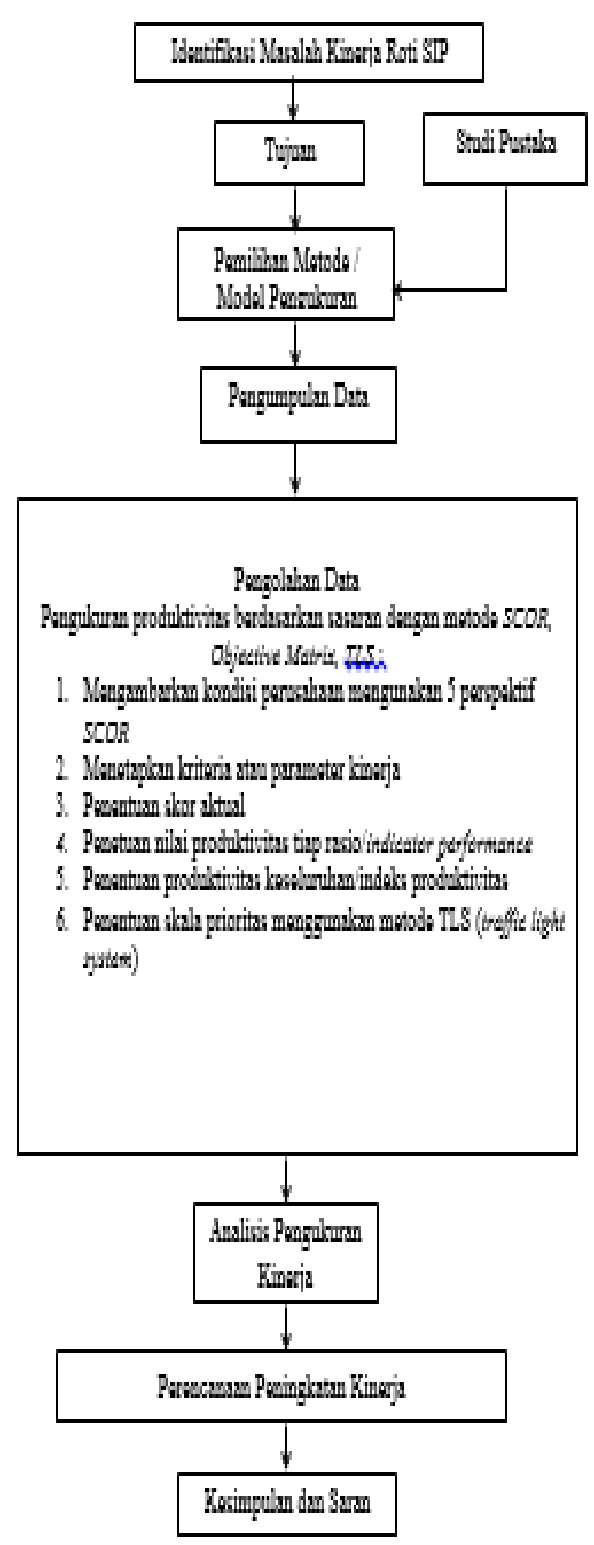




\section{METODOLOGI}

Metode yang digunakan dalam tesis ini adalah penelitian survai (survey research) dan menggunakan kuisioner sebagai alat pengumpulan data yang pokok dengan subyek penelitian adalah Unit Usaha Aneka Pangan Roti "SIP" Politeknik Negeri Jember.

Penelitian ini merupakan penelitian deskriptif yang membutuhkan langkah-langkah sistematis sebagai berikut:

1. Survei Pendahuluan Langkah awal dalam penelitian ini dimaksudkan untuk mengetahui permasalahan yang sedang dihadapi oleh perusahaan.

2. Studi Pustaka dilakukan untuk memberikan landasan teori yang berhubungan dengan pengukuran kinerja supply chain.

3. Identifikasi Masalah Pada tahap ini dilakukan pengamatan mengenai kondisi di lapangan untuk mengetahui apa dan bagaimana permasalahan yang terjadi di perusahaan.

4. Perumusan Masalah Topik penelitian dan identifikasi masalah yang telah diperoleh digunakan sebagai acuan dalam menentukan rumusan masalah yang menjadi fokus penelitian.

5. Pengumpulan Data Metode pengumpulan data yang dilakukan, antara lain:

a. Observasi

Digunakan untuk mengetahui proses produksi dan sistem pengukuranperformansi yang ada di perusahaan.

b. Wawancara dan brainstorming Digunakan untuk mengidentifikasiaktivitas supply chain perusahaan, mengidentifikasiKey Performance Indicator, dan juga mengidentifikasi network yang terjadi antar Key Performance Indicator.

c. Kuesioner Metode kuesioner dilakukan untuk melakukan validasi Key PerformanceIndicator dan juga pembobotan KeyPerformance Indicator.

d. Dokumentasi,Metode dokumentasi dilakukan terhadap data-data sekunder berikut:

1) Profil Perusahaan

2) Data rencana dan realisasi produksi

3) Data rencana dan realisasi pemasaran

4) Data hasil pemeriksaan lapangan

5) Data hasil pengolahan

6) Data jadwal perawatan mesin

7) Data hasil penjualan

8) Data jumlah komplain pelanggan

9) Data jumlah tenaga kerja produksi dan pemasaran

6. Identifikasi aktivitas supply chain Tahap identifikasi aktivitas supply chain dilakukan dengan cara mengamati,menyusun, danmengklasifikasikan aktivitas supply chain perusahaan.

7. Identifikasi Key Performance Indicator(KPI) diidentifikasi berdasarkan aktivitas supply chain yang ada di perusahaan.Selanjutnya KPI tersebut dikelompokkanberdasarkan lima proses inti pada modelSCOR yaitu Plan, Source, Make, Delivery, dan Return.

8. Validasi KPI, Tahap validasi dilakukan dengan memberikan kuesioner validasi kepada pihak perusahaan yang berkompeten dibidangnya.

9. Pembuatan network ANP Pembentukan sebuah jaringan atau network digunakan untuk melihat keterkaitan yang ada antar KPI.

10. Pembobotan KPI Pembobotan KPI dengan memberikan kuesioner yang telah dibuat berdasarkan metode Analytic Network Process (ANP).

11. Perhitungan nilai kinerja aktual KPI Nilai pencapaian kinerja masing-masing KPI didapat dari kondisi atau data sebenarnya perusahaan yang disesuaikan dengan masing-masing KPI.

12. Scoring system Sistem pemberian skor dilakukan dengan Objective Matrix (OMAX) dan kemudiankinerja supply chain dievaluasimenggunakan Traffic Light System.

13.Perhitungan nilai performansi supply chain perusahaanPerhitungan ini dilakukan untuk mengetahuiapakah performansi supply chain diperusahaan baik atau tidak.

14.Analisa dan Pembahasan Pada tahap ini dilakukan analisis dan pembahasan dari hasil pengolahan data yang telah dilakukan sebelumnya.

15.Evaluasi dan Rekomendasi Perbaikan Evaluasi dan rekomendasi perbaikan dilakukan terhadap KPI yang masih berada pada performansi kritis yang dianggap masih memerlukan perbaikan.

16.Kesimpulan dan Saran Tahap terakhir dari penelitian yang diperoleh dari hasil pengumpulan, pengolahan, dan analisis data.

\section{HASIL DAN PEMBAHASAN}

\section{Identifikasi Supply Chain Roti Aktifitas Supply Chain Perusahaan}

Aktifitas supply chain perusahaan roti SIP dimulai dengan dilakukannya pembelian bahan baku produk Roti, bahan utama tersebut antara lain: Tepung Terigu, Ragi, Garam, dan Air. Untuk mendapatkan hasil produk yang baik maka dilakukan analisa terhadap keempat bahan utama tersebut. Mutu tepung terigu dilakukan analisa mutu fisik diantaranya: warna, bau, rasa dan tekstur, begitu juga untuk ketiga bahan utama yang lain dilakukan uji yang sama, apabila ada penyimpangan terhadap bahan yang telah 
ditentukan oleh perusahaan maka akan dikembalikan atau minta penggantian.

Penggantian bahan biasanya dilakukan apabila bahan tersebut tidak memenuhi kriteria dari perusahaan, pengembalian bahan merupakan tanggung jawab dari perusahaan pemasok bahan baku yang sudah bermitra dengan UPT. Aneka Pangan. Apabila bahan baku dinyatakan lolos kriteria analisa mutu fisik maka akan disimpan diruang penyimpanan bahan baku dan dibayar sesuai dengan jumlah tagihan. Proses pembayaran bahan baku tersebut dibayar oleh manager keuangan secara tunai.

Bahan baku yang dinyatakan lulus, akan di produksi roti. Produksi roti akan disesuaikan dengan analisa perkiraan dari koordinator produksi roti SIP. Koordinator produksi roti SIP memperkirakan jumlah produksi roti manis berdasarkan perkiraan penjualan minggu sebelumnya yang diterima dari marketing / sales keliling roti SIP dan hasil penjualan total minggu sebelumnya.

Proses produksi roti SIP dimulai dari penimbangan bahan, mixing, fermentasi awal, penimbangan, pengisian, pembentukan, fermentasi akhir, pengovenan, pendinginan, dan pengemasan.

Roti yang dihasilkan kemudian akan dipasarkan dengan 3 sistem pemasaran, yaitu 1 . Sales motor, Dalam saluran distribusi ini yang menjalankan fungsi distribusi adalah sales. Sales disini adalah pekerja dari perusahaan yang bertugas menjual produknya langsung ke konsumen. 2. Distributor, Dalam saluran distribusi ini yang menjalankan fungsi distribusi adalah orang atau perusahaan dagang yang membeli atau mengoper hak milik dan menjual barang-barang dagangan khususnya proyek yang dihasilkan oleh Unit Usaha Aneka Pangan Roti "SIP". Pihak perusahaan hanya menyiapkan produk jadi, setelah itu pihak perantara membantu didalam bidang promosi, penjualan dan pendistribusian barang kepada konsumen. 3. Langsung, Untuk saluran distribusi ini perusahaan mempunyai Show Room tempat menjual barang hasil produksinya, jadi konsumen bisa langsung datang ke tempat dan bertransaksi langsung sesuai dengan kesepakatan produsen ke konsumen.

\section{Aliran yang dikelola}

Berdasarkan aktivitas supply chain yang ada di perusahaan, maka digambarkan aliran yang dikelola. Dalam konseptual supply chain biasanya ada 3 macam aliran yang harus dikelola. Pertama adalah aliran barang yang mengalir dari hulu (upstream) ke hilir (downstream). Kedua adalah aliran uang dan sejenisnya yang mengalir dari hilir ke hulu. Sedangkan ketiga adalah aliran informasi yang bisa terjadi dari hulu ke hilir ataupun sebaliknya (Pujawan, 2010). Untuk gambaran kerangka aktivitas supply chain mulai dari supplier hingga sampai kepada end customer beserta aliran yang dikelola Roti SIP.

\section{Klasifikasi Aktivitas Supply Chain Berdasarkan Model SCOR}

Aktivitas supply chain diklasifikasikan berdasarkan lima perspektif seperti yang terlihat pada Gambar 2. Untuk perspektif plan, aktivitas yang dilakukan adalah membuat perencanaan terlebih dahulu sehingga dapat mencapai hasil yang maksimal. Perencanaan dilakukan pada 4 aktivitas supply chain, yaitu penerimaan supplier tepung terigu, supplier air, supplier ragi roti, supplier garam, pemasaran motor dan pemasaran langsung. Perspektif source dapat diklasifikasikan siapa saja pihak-pihak yang digunakan dalam menjalankan aktifitas utama perusahaan (produksi) yaitu supplier tepung terigu, air, ragi roti dan garam.

Selanjutnya, aktivitas supply chain yang termasuk dalam perspektif make adalah proses produksi yang dilakukan oleh bagian pengolahan roti SIP, untuk perspektif deliver, aktifitas proses pengiriman yang dilakukan dalam mendukung pengolahan roti merupakan aktifitas yang dilakukan oleh keseluruhan supply chain.pengiriman dilakukan mulai bahan baku utama hingga produk jadi roti yang siap dipasarkan sampai ketangan konsumen. Untuk perspektif return, aktifitas yang dilakukan adalah proses pengembalian karena produk yang diterima tidak sesuai dengan harapan atau pesanan. Pengembalian dilakukan pada aktifitas supply chain dari perusahaan kepada supplier dan customer kepada perusahaan.

\section{Identifikasi key performance indicator}

Dalam menidentifikasi KPI, langkah awal yang dilakukan adalah penyusunan visi dan misi perusahaan yang di tuangkan dalam target perusahaan. Dari visi misi tersebut, selanjutnya KPI disesuaikan dengan aktifitas supply chain yang ada diperusahaan sesuai model SCOR yang terdiri dari lima perspektif. Sesuai dengan kondisi perusahaan, KPI yang diperoleh pada awalnya 28 KPI. Dari hasil kuisioner validasi yang diberikan dan wawancara kepada perusahaan, maka di peroleh $22 \mathrm{KPI}$ yang valid yang terdiri dari $4 \mathrm{KPI}$ perpektif plan, 5 KPI perspektif source, 5 KPI perspektif make, $5 \mathrm{KPI}$ perspektif deliver, $3 \mathrm{KPI}$ perspektif return. Hasil KPI yang tervalidasi dapat dilihat pada lampiran.

Pembobotan key performance indicator
Pembobotan KPI bertujuan r untuk
membobotkan atau menentukan tingkat
kepentingan perspektif dan KPI dari sistem


pengukuran kinerja yang ada di perusahaan. Sistem pembobotan KPI ini dilakukan dengan menggunakan kuesioner yang diberikan kepadaresponden yang mewakili bagian produksi dan pimpinan roti sip. Hasil kuesioner selanjutnya diolah menggunakan bantuan software Expert Choice fersi 9. Dari hasil kuesioner yang diberikan, dilakukan perhitungan nilai inconsistency ratio. Langkah awal yang dilakukan adalah melakukan perhitungan nilai inconsistency ratio untuk setiap pernyataan keterkaitan dari masing-masing responden. Dari hasil perhitungan diperoleh hasil bahwa keseluruhan keterkaitan baik itu dari responden 1 maupun responden 2

memiliki nilai inconsistency ratio $\leq 0,1$, yang berarti hasil pengisian kuesioner telahkonsisten. Setelah hasil kuesioner dari masingmasing responden dinyatakan konsisten, maka selanjutnya dilakukan perhitungan nilai inconsistency ratio untuk nilai akhir gabungan dari kedua responden (geometric mean). Dari hasil perhitungan, kemudian diperoleh nilai inconsistency ratio perbandingan berpasangan untuk setiap keterkaitan yang ada yaitu $\leq 0,1$.Hal ini menunjukkan bahwa perhitungan untuknilai akhir gabungan telah konsisten dan dapatditerima.

Scoring system dengan Objective matrix (OMAX) dan Traffic light system (TLS)

Perhitungan OMAX dilakukan untuk memperoleh nilai masing-masing KPI untuk setiap level yang ada dan selanjutnya akan diketahui posisi pencapaian kinerja ada pada level berapa, dan termasuk dalam kategori warna apa sesuai dengan Traffic Light System. Pada metode OMAX, terdapat 3 jenis target yang perlu dipertimbangkan dalam melakukan perhitungan, yaitu:

1. Target ideal merupakan target maksimal pencapaian kinerja perusahaan. Target ideal ini diletakkan pada level 10 .

2. Target baik (achievable) merupakan nilai target yang mudah untuk dicapai. Target baik ini diletakkan pada level 8 sebagai batas indikator hijau dan kuning

3. Target peringatan (warning) merupakan nilai target pencapaian minimal. Target

warningini diletakkan pada level 4 sebagai batas indikator kuning dan merah. Jika nilai kinerja kurang dari target warning, maka kinerja dikatakan buruk.

Sedangkan, level 0 diisi dengan nilai terendah yang mungkin dicapai dalam keadaan terburuk. Untuk level lainnya dapat diisi dengan menggunakan rumus skala linear pada Persamaan 1 (Christopher, 2003).

$$
\Delta \mathrm{X}_{\mathrm{L}-\mathrm{H}}=\frac{\overline{\mathrm{Y}}_{\mathrm{H}}-\mathrm{Y}_{\mathrm{L}}}{\mathrm{X}_{\mathrm{H}}-\mathrm{X}_{\mathrm{L}}}
$$

Keterangan: = interval antara level high dengan low

$\mathrm{XH}=$ level high

$\mathrm{XL}=$ level low

$\mathrm{YH}=$ angka pada level high

$\mathrm{YL}=$ angka pada level low

Setelah diperoleh nilai untuk setiap level maka selanjutnya pada bagian monitoring dapat diisi berdasarkan posisi level pada angka performance yang merupakan performansisupply chain perusahaan. Untuk mengisi level di bagian monitoring, langkah yang dilakukan adalah dengan menggunakan rumus interpolasi. Nilai level yang diisikan pada bagian monitoring dan nilai tersebut akan dikategorikan berdasarkan Traffic Light System. Untuk weight diisi dengan nilai bobot indicator kinerja. Nilai value merupakan hasil perkalian antara nilai level dan nilai weight. Tabel skema pengukuran kinerja tiap perspektif dapat dilihat pada Tabel.

Dari hasil pengukuran kinerja setiap KPI, maka dilakukan pengukuran performansi supplychain perusahaan secara keseluruhan.

\begin{tabular}{|c|c|c|c|c|}
\hline pektif & $\begin{array}{c}\text { Bobot } \\
\text { perpektif }\end{array}$ & KPI & Bobot & $\begin{array}{c}\text { Bobot } \\
\text { Total }\end{array}$ \\
\hline \multirow{4}{*}{ Plan } & \multirow{4}{*}{0.249} & P1 & 0.27 & 0.06 \\
\hline & & $\mathrm{P} 2$ & 0.42 & 0.1 \\
\hline & & P3 & 0.14 & 0.03 \\
\hline & & $\mathrm{P} 4$ & 0.14 & 0.03 \\
\hline \multirow{5}{*}{ Source } & \multirow{5}{*}{0.147} & $\mathrm{~S} 1$ & 0.2 & 0.02 \\
\hline & & $\mathrm{S} 2$ & 0.16 & 0.02 \\
\hline & & S3 & 0.1 & 0.01 \\
\hline & & $\mathrm{S} 4$ & 0.18 & 0.02 \\
\hline & & S5 & 0.33 & 0.04 \\
\hline \multirow{5}{*}{ Make } & \multirow{5}{*}{0.129} & M1 & 0.341 & 0.04 \\
\hline & & M2 & 0.251 & 0.03 \\
\hline & & M3 & 0.101 & 0.01 \\
\hline & & M4 & 0.128 & 0.01 \\
\hline & & M5 & 0.18 & 0.02 \\
\hline \multirow{5}{*}{ Deliver } & \multirow{5}{*}{0.082} & D1 & 0.315 & 0.02 \\
\hline & & D2 & 0.182 & 0.01 \\
\hline & & D3 & 0.118 & 0.009 \\
\hline & & D4 & 0.105 & 0.008 \\
\hline & & D5 & 0.277 & 0.02 \\
\hline \multirow{3}{*}{ Return } & \multirow{3}{*}{0.392} & R1 & 0.493 & 0.193 \\
\hline & & $\mathrm{R} 2$ & 0.311 & 0.12 \\
\hline & & R3 & 0.196 & 0.07 \\
\hline
\end{tabular}


M. Rizal Umami, Ridawan Iskandar dan Ujang Suryadi, Analisis Kinerja SUUPLY CHAIN Menggunakan Model Scor (Studi Kasus pada roti “SIP” Politeknik Negeri Jember)

\begin{tabular}{|c|c|c|c|c|c|}
\hline \multicolumn{6}{|c|}{$\begin{array}{c}\text { Skema pengukuran performansi supply chain } \\
\text { perspektif plan }\end{array}$} \\
\hline KPI & & 1 & P2 & P3 & P4 \\
\hline $\begin{array}{l}\text { Perfor } \\
\text { mansi }\end{array}$ & \multicolumn{2}{|c|}{89.99} & 90.78 & 86.96 & 95.65 \\
\hline \multirow{11}{*}{ 质 } & $\begin{array}{l}1 \\
0\end{array}$ & $\begin{array}{r}116 \\
.85\end{array}$ & 90.76 & 99.93 & 99.97 \\
\hline & 9 & $\begin{array}{r}113 \\
.77 \\
\end{array}$ & 90.67 & 98.54 & 98.98 \\
\hline & 8 & $\begin{array}{r}110 \\
.69 \\
\end{array}$ & 90.58 & 97.15 & 97.99 \\
\hline & 7 & $\begin{array}{r}107 \\
.61 \\
\end{array}$ & 90.49 & 95.76 & 97.00 \\
\hline & 6 & $\begin{array}{r}104 \\
.53 \\
\end{array}$ & 90.40 & 94.37 & 96.01 \\
\hline & 5 & $\begin{array}{r}101 \\
.45\end{array}$ & 90.31 & 92.98 & 95.02 \\
\hline & 4 & $\begin{array}{l}98 . \\
37\end{array}$ & 90.22 & 91.59 & 94.03 \\
\hline & 3 & $\begin{array}{r}95 . \\
29 \\
\end{array}$ & 90.13 & 90.22 & 93.04 \\
\hline & 2 & $\begin{array}{r}91 . \\
70 \\
\end{array}$ & 89.87 & 86.22 & 92.20 \\
\hline & 1 & $\begin{array}{r}88 . \\
11 \\
\end{array}$ & 89.63 & 82.24 & 86.36 \\
\hline & 0 & $\begin{array}{r}84 . \\
52 \\
\end{array}$ & 89.39 & 78.26 & 80.52 \\
\hline Level & & $\begin{array}{c}1.5 \\
2\end{array}$ & 10 & 2.18 & 5.63 \\
\hline Bobot & & $\begin{array}{c}0.2 \\
7 \\
\end{array}$ & 0.42 & 0.14 & 0.14 \\
\hline Nilai & & $\begin{array}{c}0.4 \\
1\end{array}$ & 4.20 & 0.31 & 0.79 \\
\hline Plan & & & & & \\
\hline
\end{tabular}

Skema pengukuran performansi supply chain perspektif Source

\begin{tabular}{|c|c|c|c|c|c|c|}
\hline \multicolumn{2}{|c|}{ KPI } & S1 & S2 & S3 & S4 & S5 \\
\hline \multicolumn{2}{|c|}{ Performansi } & 50.00 & $\begin{array}{c}70.0 \\
0\end{array}$ & $\begin{array}{c}90.0 \\
0\end{array}$ & 90.00 & 5.00 \\
\hline \multirow{22}{*}{ 소동 } & & & 70.0 & 99.9 & & \\
\hline & 10 & 49,95 & 0 & 8 & 95.00 & 5.00 \\
\hline & & & 68,6 & 99.0 & & \\
\hline & 9 & 49,54 & 9 & 3 & 93.75 & 4.94 \\
\hline & & & 67,3 & 98.0 & & \\
\hline & 8 & 49,13 & 8 & 8 & 92.50 & 4.88 \\
\hline & & & 66,0 & 97.1 & & \\
\hline & 7 & 48,72 & 7 & 3 & 91.25 & 4.82 \\
\hline & & & 64,7 & 96.1 & & \\
\hline & 6 & 48,31 & 6 & 8 & 90.00 & 4.76 \\
\hline & & & 63,4 & 95.2 & & \\
\hline & 5 & 47,9 & 5 & 3 & 88.75 & 4.70 \\
\hline & & & 62,1 & 94.2 & & \\
\hline & 4 & 47,49 & 4 & 8 & 87.50 & 4.64 \\
\hline & & & 60,8 & 93,3 & & \\
\hline & 3 & 47,08 & 3 & 3 & 86,25 & 4,58 \\
\hline & & & 53,8 & 90.5 & & \\
\hline & 2 & 41,38 & 8 & 4 & 84.16 & 4.38 \\
\hline & & & 46,9 & 87.7 & & \\
\hline & 1 & 35,69 & 4 & 7 & 82.08 & 4.19 \\
\hline & & & 40.0 & 85.0 & & \\
\hline & 0 & 30.00 & 0 & 0 & 80.00 & 4.00 \\
\hline \multicolumn{2}{|l|}{ Level } & 10 & 10 & 1.8 & 6 & 10 \\
\hline \multicolumn{2}{|l|}{ Bobot } & 0,20 & 0,16 & 0.1 & 0.18 & 0.33 \\
\hline \multicolumn{2}{|l|}{ Nilai } & 2.00 & 1.60 & 0.18 & 1.08 & 3.30 \\
\hline \multicolumn{2}{|l|}{ SOURC } & & \multicolumn{2}{|c|}{8.16} & & \\
\hline
\end{tabular}

Skema pengukuran performansi supply chain perspektif

\begin{tabular}{|c|c|c|c|c|c|c|}
\hline \multicolumn{2}{|c|}{ KPI } & M1 & M2 & M3 & M4 & M5 \\
\hline \multirow{2}{*}{\multicolumn{2}{|c|}{ Performansi }} & & & & & 14.0 \\
\hline & & 95,65 & 6.00 & 15.00 & 86.96 & 0 \\
\hline \multirow{22}{*}{ 空 } & & & & & & 15.9 \\
\hline & 10 & 99.97 & 6.95 & 21.99 & 99.95 & 5 \\
\hline & & & & & & 15.7 \\
\hline & 9 & 98.98 & 6.79 & 20.42 & 98.56 & 3 \\
\hline & & & & & & 15.5 \\
\hline & 8 & 97.99 & 6.63 & 18.85 & 97.17 & 1 \\
\hline & & & & & & 15.2 \\
\hline & 7 & 97.00 & 6.47 & 17.28 & 95.78 & 9 \\
\hline & & & & & & 15.0 \\
\hline & 6 & 96.01 & 6.31 & 15.71 & 94.39 & 7 \\
\hline & & & & & & 14.8 \\
\hline & 5 & 95.02 & 6.15 & 14.14 & 93.00 & 5 \\
\hline & & & & & & 14.6 \\
\hline & 4 & 94.03 & 5.99 & 12.57 & 91.61 & 3 \\
\hline & & & & & & 14.4 \\
\hline & 3 & 93.04 & 5.83 & 11.00 & 90.22 & 1 \\
\hline & & & & & & 13.9 \\
\hline & 2 & 88.86 & 5.54 & 7.32 & 86.22 & 4 \\
\hline & & & & & & 13.4 \\
\hline & 1 & 84.69 & 5.27 & 3.66 & 82.24 & 7 \\
\hline & & & & & & 13.0 \\
\hline & 0 & 80.52 & 5.00 & 0.00 & 78.26 & 0 \\
\hline \multicolumn{2}{|l|}{ Level } & 5.63 & 4.06 & 5.54 & 2.18 & 2.12 \\
\hline \multicolumn{2}{|l|}{ Bobot } & 0.341 & 0.251 & 0.101 & 0.128 & 0.18 \\
\hline \multicolumn{2}{|l|}{ Nilai } & 1.91 & 1.01 & 0.55 & 0.27 & 0.38 \\
\hline
\end{tabular}

\begin{tabular}{|c|c|c|c|c|c|c|}
\hline \multicolumn{2}{|c|}{ KPI } & D1 & D2 & D3 & D4 & D5 \\
\hline \multirow{2}{*}{\multicolumn{2}{|c|}{ Performansi }} & & 100.0 & & & \\
\hline & & 89,99 & 0 & 20.00 & 6.00 & 3000.00 \\
\hline \multirow{22}{*}{ 武 } & & & 100.0 & & & \\
\hline & 10 & 116.85 & 0 & 15.01 & 6.95 & 3000.00 \\
\hline & & & 100.0 & & & \\
\hline & 9 & 113.77 & 0 & 15.96 & 6.79 & 3000.00 \\
\hline & & & 100.0 & & & \\
\hline & 8 & 110.69 & 0 & 16.91 & 6.63 & 3000.00 \\
\hline & & & 100.0 & & & \\
\hline & 7 & 107.61 & 0 & 17.86 & 6.47 & 3000.00 \\
\hline & & & 100.0 & & & \\
\hline & 6 & 104.53 & 0 & 18.81 & 6.31 & 3000.00 \\
\hline & & & 100.0 & & & \\
\hline & 5 & 101.45 & 0 & 19.76 & 6.15 & 3000.00 \\
\hline & & & 100.0 & & & \\
\hline & 4 & 98.37 & 0 & 20.71 & 5.99 & 3000.00 \\
\hline & & & 100.0 & & & \\
\hline & 3 & 95.29 & 0 & 21.66 & 5.83 & 3000.00 \\
\hline & & & 100.0 & & & \\
\hline & 2 & 91.70 & 0 & 24.44 & 5.54 & 3000.00 \\
\hline & & & 100.0 & & & \\
\hline & 1 & 88.11 & 0 & 27.22 & 5.27 & 3000.00 \\
\hline & & & 100.0 & & & \\
\hline & 0 & 84.52 & 0 & 30.00 & 5.00 & 3000.00 \\
\hline \multicolumn{2}{|l|}{ Level } & 1.52 & 10 & 4.75 & 4.06 & 10 \\
\hline \multicolumn{2}{|l|}{ Bobot } & 0.315 & 0.182 & 0.118 & 0.105 & 0.277 \\
\hline \multicolumn{2}{|l|}{ Nilai } & 0.47 & 1.80 & 0.56 & 0.40 & 2.7 \\
\hline \multicolumn{2}{|c|}{$\begin{array}{l}\text { DELIVE } \\
R\end{array}$} & & & 5.93 & & \\
\hline
\end{tabular}


Skema pengukuran performansi supply chain perspektif Return

\begin{tabular}{|c|c|c|c|c|}
\hline \multicolumn{2}{|c|}{ KPI } & R1 & $\mathbf{R 2}$ & $\mathbf{R 3}$ \\
\hline \multicolumn{2}{|c|}{ Performansi } & 114.00 & 1.00 & 5.00 \\
\hline \multirow{11}{*}{ 预 } & 10 & 20.99 & 0.07 & 4.98 \\
\hline & 9 & 37.80 & 1.01 & 5.22 \\
\hline & 8 & 54.61 & 1.05 & 5.46 \\
\hline & 7 & 71.42 & 1.09 & 5.70 \\
\hline & 6 & 88.23 & 1.13 & 5.94 \\
\hline & 5 & 105.04 & 1.17 & 6.18 \\
\hline & 4 & 121.85 & 1.21 & 6.42 \\
\hline & 3 & 138.66 & 1.25 & 6.66 \\
\hline & 2 & 211.44 & 1.50 & 7.78 \\
\hline & 1 & 284.22 & 1.75 & 8.89 \\
\hline & 0 & 357.00 & 2.00 & 10.00 \\
\hline \multicolumn{2}{|l|}{ Level } & 4.47 & 9.01 & 9.92 \\
\hline \multicolumn{2}{|l|}{ Bobot } & 0.493 & 0.311 & 0.196 \\
\hline \multicolumn{2}{|l|}{ Nilai } & 2.20 & 2.80 & 1.94 \\
\hline RETURI & & \multicolumn{2}{|c|}{6.95} & \\
\hline
\end{tabular}

\begin{tabular}{|c|c|c|c|c|c|}
\hline \multicolumn{6}{|c|}{ Pengukuran Performansi Supply chain Perusahaan } \\
\hline No & Perspektif & $\begin{array}{l}\text { Nilai } \\
\text { level }\end{array}$ & KPI & $\begin{array}{c}\text { Bobot } \\
\text { total }\end{array}$ & $\begin{array}{l}\text { Nilai } \\
\text { level }\end{array}$ \\
\hline \multirow{4}{*}{1} & \multirow{4}{*}{ Plan } & \multirow{4}{*}{5.70} & P1 & 0.06 & 1.52 \\
\hline & & & P2 & 0.1 & 10 \\
\hline & & & P3 & 0.03 & 2.18 \\
\hline & & & $\mathrm{P} 4$ & 0.03 & 5.63 \\
\hline \multirow{5}{*}{2} & \multirow{5}{*}{ Source } & \multirow{5}{*}{8.16} & S1 & 0.02 & 10 \\
\hline & & & S2 & 0.02 & 10 \\
\hline & & & S3 & 0.01 & 1.8 \\
\hline & & & S4 & 0.02 & 6 \\
\hline & & & S5 & 0.04 & 10 \\
\hline \multirow{5}{*}{3} & \multirow{5}{*}{ Make } & \multirow{5}{*}{4.12} & M1 & 0.04 & 5.63 \\
\hline & & & M2 & 0.03 & 4.06 \\
\hline & & & M3 & 0.01 & 5.54 \\
\hline & & & M4 & 0.01 & 2.18 \\
\hline & & & M5 & 0.02 & 2.12 \\
\hline \multirow{5}{*}{4} & \multirow{5}{*}{ Deliver } & \multirow{5}{*}{5.93} & D1 & 0.02 & 1.52 \\
\hline & & & D2 & 0.01 & 10 \\
\hline & & & D3 & 0.009 & 4.75 \\
\hline & & & D4 & 0.008 & 4.06 \\
\hline & & & D5 & 0.02 & 10 \\
\hline \multirow{3}{*}{5} & \multirow{3}{*}{ Return } & \multirow{3}{*}{6.95} & R1 & 0.193 & 4.47 \\
\hline & & & $\mathrm{R} 2$ & 0.12 & 9.01 \\
\hline & & & R3 & 0.07 & 9.92 \\
\hline \multicolumn{2}{|c|}{$\begin{array}{c}\text { Total indeks } \\
\text { performansi Supply }\end{array}$} & \multicolumn{4}{|c|}{5.08} \\
\hline
\end{tabular}

Hasil nilai total indeks performansi supply chain adalah sebesar 5.08, yang termasuk dalam kategori kuning. Hal ini menunjukkan bahwa performansi supply chain roti SIP belum mencapai performa yang diharapkan. Untuk itu pihak manajemen harus berhati-hati dengan adanya berbagai macam kemungkinan yang dapat menurunkan performansi supply chain perusahaan dan tetap melakukan peningkatan performansi secara terus menerus.

Hasil pengukuran pada tingkat perspektif yang berada pada kategori kuning, yaitu plan,make,deliverdan return. Sedangkan untuk perspektif source masih berada pada kategori hijau. Perspektif source memiliki nilai tertinggi yaitu 8.16 dimana nilai tersebut menunjukkan bahwa performansi perusahaan dalam mencari sumber bahan baku utama sangat baik dalam pemenuhan kebutuhan akan bahan baku roti.
Nilai pencapaian kedua, ketiga, keempat dan kelima adalah perspektif return dengan nilai 6.95. nilai ini menunjukkan bahwa perspektif ini belum mencapai target perusahaan karena masih tingginya pengembalian dari konsumen ke produsen. perspektifdeliver dengan nilai 5.93 nilai ini menunjukkan bahwa perspektif ini belum mencapai target perusahaan karena pengiriman dari perusahan ke konsumen atau perusahaan ke distributor masih terlambat. perspektifplan dengan nilai 5.70 nilai ini menunjukkan bahwa perspektif ini belum mencapai target perusahaan karena pengadaan bahan baku masih sering terjadi kekurangan pasokan dan perpektif make dengan nilai 4.12. nilai ini menunjukkan bahwa perspektif ini belum mencapai target perusahaan karena masih terbatasnya jumlah tenaga kerja yang berpengalaman. Untuk itu perlu dilakukan perbaikan perspektif tersebut dalam meningkatkan performansi perusahan.

Dari hasil pengukuran berdasarkan KPI, setiap KPI memiliki nilai pencapaian yang berbeda beda. Berdasarkan kategori dalam traffic light system, maka diperoleh $8 \mathrm{KPI}$ termasuk kategori hijau, 8 KPI termasuk kategori kuning dan 6 KPI termasuk kategori merah.

Setelah melakukan analisis hasil pengukuran performansi supply chain, maka selanjutnya perlu melakukan evaluasi dan rekomendasi perbaikan. Untuk melakukan rekomendasi perbaikan, analisis dilakukan pada indicator kinerja yang berada pada kategori kuning dan merah, indokator kinerja yang berada pada kategori kuning dan merah sama-sama memerlukan perbaikan agar dapat meningkatkan performansinya. Namun, indicator kinerja yang berada pada kategori merah harus mendapatkan prioritas terlebih dahulu dalam tindakan perbaikannya karena memiliki performa yang jauh dibawah ketentuan atau target yang telah ditetapkan oleh perusahaan roti SIP. 


\begin{tabular}{|c|c|c|}
\hline Kategori & Kode & KPI \\
\hline \multirow{6}{*}{ Merah } & $\mathrm{P} 1$ & $\begin{array}{l}\text { Persentase kesesuaian } \\
\text { jumlah produksi roti } \\
\text { dengan target pemasaran } \\
\text { yang direncanakan per } \\
\text { hari }\end{array}$ \\
\hline & P3 & $\begin{array}{l}\text { Persentase jumlah } \\
\text { peralatan yang dapat } \\
\text { digunakan dalam proses } \\
\text { pembuatan roti SIP per } \\
\text { hari terhadap peralatan } \\
\text { yang diperlukan }\end{array}$ \\
\hline & $\mathrm{S} 3$ & $\begin{array}{l}\text { Jumlah bahan baku } \\
\text { komersial yang dapat } \\
\text { disediakan oleh suplier }\end{array}$ \\
\hline & M4 & $\begin{array}{l}\text { Persentase jumlah } \\
\text { peralatan produksi yang } \\
\text { layak digunakan selama } \\
\text { proses produksi }\end{array}$ \\
\hline & M5 & $\begin{array}{l}\text { Jumlah tenaga kerja yang } \\
\text { berpengalaman }\end{array}$ \\
\hline & D1 & $\begin{array}{l}\text { Persentase kesesuaian } \\
\text { realisasi penjualan roti SIP } \\
\text { dengan target yang telah } \\
\text { direncanakan }\end{array}$ \\
\hline \multirow{8}{*}{ Kuning } & $\mathrm{P} 4$ & $\begin{array}{l}\text { Persentase jumlah realisasi } \\
\text { bahan baku yang } \\
\text { digunakan dalam proses } \\
\text { pembuatan roti SIP per } \\
\text { hari terhadap jumlah } \\
\text { bahan baku yang } \\
\text { direncanakan }\end{array}$ \\
\hline & $\mathrm{S} 4$ & $\begin{array}{l}\text { Jumlah produksi } \\
\text { berdasarkan analisa } \\
\text { manajer produksi }\end{array}$ \\
\hline & M1 & $\begin{array}{l}\text { Persentase kesesuaian } \\
\text { jumlah bahan baku } \\
\text { terhadap jumlah produksi } \\
\text { roti SIP }\end{array}$ \\
\hline & M2 & $\begin{array}{l}\text { Lama waktu sampai } \\
\text { proses produksi selesai }\end{array}$ \\
\hline & M3 & $\begin{array}{l}\text { Persentase ketepatan } \\
\text { jadwal perawatan mesin- } \\
\text { mesin produksi }\end{array}$ \\
\hline & D3 & $\begin{array}{l}\text { Jumlah pengiriman roti } \\
\text { SIP yang terlambat kepada } \\
\text { pihak penyalur }\end{array}$ \\
\hline & D4 & $\begin{array}{l}\text { Waktu yang dibutuhkan } \\
\text { sejak roti dipesan hingga } \\
\text { siap kirim }\end{array}$ \\
\hline & $\mathrm{R} 1$ & $\begin{array}{l}\text { Jumlah } \\
\text { penggantian/pengembalian } \\
\text { roti sip }\end{array}$ \\
\hline
\end{tabular}

Evaluasi ini dilakukan dengan menggunakan metode Root Cause Analysis
(RCA) untuk memudahkan dalam menemukan akar permasalahan dan mencari solusi yang tepat. Selain itu, pemanfaatan RCA dalam analisis perbaikan kinerja menurut Latino dan Kenneth (2006) dapat memudahkan pelacakan terhadap faktor yang mempengaruhi kinerja.

Dari hasil evaluasi tersebut, diperoleh 14 akar permasalahan tidak tercapainya performansi KPI yang berada pada kategori merah dan kuning yaitu: 1.Sehari sebelum produksi baru direncanakan produksi.

2.Belum ada kebijakan tentang adanya pelatihan.

3.Tidak ada karyawan yang ditugaskan untuk melakukan pendataan stok bahan baku roti SIP.

4. Tidak ada program penambahan peralatan baru.

5.Tidak ada kebijakan perekrutan karyawan dalam bidang pengolahan pangan.

6.Tidak ada penambahan jumlah marketing motor.

7.Kurangnya karyawan pengawas pada fermentasi roti.

8.Tidak terjadwal secara jelas agenda rutin rapat perusahaan.

9.Rasa roti manis favorit hanya ada satu.

10.Lokasi yang sempit menyebabkan tidak cukup untuk fermentor baru

11.Perawatan belum menjadi prioritas.

12.Tidak ada karyawan pengawas pengiriman.

13.Sumber daya manusia bidang pemasaran masih kurang.

14.Sumber daya manusia bidang pemasaran masih kurang.

Selanjutnya, dari masing-masing akar permasalahan tersebut akan diperoleh beberapa rekomendasi perbaikan yang dapat digunakan untuk meningkatkan performansi roti SIP.

1.Perencanaan dilakukan dalam periode tahunan, bulanan, mingguan dan harian.

2. Perlu diadakan pelatihan untuk karyawan.

3.Menugaskan karyawan untuk melakukan pendataan stok bahan baku roti SIP.

4. perlu adanya program penambahan peralatan baru.

5.Perlu adanya kebijakan perekrutan karyawan dalam bidang pengolahan pangan

6.Perlunya penambahan jumlah marketing motor

7.Penambahan karyawan pengawas pada fermentasi roti

8.Perlu membuat jadwal agenda rutin rapat perusahaan.

9.Penambahan jenis roti manis yang diminati konsumen.

10.Menambah lokasi ruang fermentor baru.

11.Memprioritaskan perawatan mesin produksi.

12.Memberikan tugas baru karyawan pengawas pengiriman.

13.Menambah sumber daya manusia bidang pemasaran. 
14.Menambah sumber daya manusia bidang pemasaran.

\section{KESIMPULAN DAN SARAN \\ Kesimpulan}

Dari hasil pengolahan dan analisis hasil yang telah dilakukan, terdapat beberapa hasil yang diperoleh dari penelitian ini, yaitu sebagai berikut:

1. di peroleh $22 \mathrm{KPI}$ yang valid yang terdiri dari 4 KPI perpektif plan, 5 KPI perspektif source, 5 KPI perspektif make, 5 KPI perspektif deliver, 3 KPI perspektif return.

2. Hasil pengukuran pada tingkat perspektif yang berada pada kategori kuning, yaitu plan,make,deliverdan return. Sedangkan untuk perspektif source masih berada pada kategori hijau. Perspektif source memiliki nilai tertinggi yaitu 8.16 dimana nilai tersebut menunjukkan bahwa performansi perusahaan dalam mencari sumber bahan baku utama sangat baik dalam pemenuhan kebutuhan akan bahan baku roti.

3. Nilai pencapaian kedua, ketiga, keempat dan kelima adalah perspektif return dengan nilai 6.95. nilai ini menunjukkan bahwa perspektif ini belum mencapai target perusahaan karena masih tingginya pengembalian dari konsumen ke produsen. perspektifdeliver dengan nilai 5.93 nilai ini menunjukkan bahwa perspektif ini belum mencapai target perusahaan karena pengiriman dari perusahan ke konsumen atau perusahaan ke distributor masih terlambat. perspektifplan dengan nilai 5.70 nilai ini menunjukkan bahwa perspektif ini belum mencapai target perusahaan karena pengadaan bahan baku masih sering terjadi kekurangan pasokan dan perpektif make dengan nilai 4.12. nilai ini menunjukkan bahwa perspektif ini belum mencapai target perusahaan karena masih terbatasnya jumlah tenaga kerja yang berpengalaman. Untuk itu perlu dilakukan perbaikan perspektif tersebut dalam meningkatkan performansi perusahan.

4. rekomendasi perbaikan yang dapat digunakan untuk meningkatkan performansi roti SIP.

1.Perencanaan dilakukan dalam periode tahunan, bulanan, mingguan dan harian.

2. Perlu diadakan pelatihan untuk karyawan.

3. Menugaskan karyawan untuk melakukan pendataan stok bahan baku roti SIP.

4. perlu adanya program penambahan peralatan baru.

5.Perlu adanya kebijakan perekrutan karyawan dalam bidang pengolahan pangan

6.Perlunya penambahan jumlah marketing motor

7.Penambahan karyawan pengawas pada fermentasi roti
8.Perlu membuat jadwal agenda rutin rapat perusahaan.

9.Penambahan jenis roti manis yang diminati konsumen.

10.Menambah lokasi ruang fermentor baru.

11.Memprioritaskan perawatan mesin produksi.

12.Memberikan tugas baru karyawan pengawas pengiriman.

13.Menambah sumber daya manusia bidang pemasaran.

14.Menambah sumber daya manusia bidang pemasaran.

\section{Saran}

Perlu dilakukan penelitian lebih jauh jaringan atau Network digunakan untuk melihat keterkaitan yang ada antar KPI.

\section{DAFTAR PUSTAKA}

Chopra S, Meindl P. 2007. Supply Chain Management, Strategy, Planning, and Operations Third Edition. New Jersey (US): Pearson Education, Inc.

Christopher, William F. dan Thor, Carl G.(2003). Handbook for ProductivityMeasurement and Improvement. Portland: Productivity Press.

Indrajit, R.E, Djokopranoto R. 2002. Konsep Manajemen Supply Chain. PTGramedia Widiasarana Indonesia. Jakarta.

Latino RJ, Kenneth CL. 2006. Root Cause Analysis: Improving Performance for Bottom -Line Results. Florida: CRC Press.

Mentzer JT, DeWitt W, Keebler JS, Min S, Nix NW, Smith CD, Zacharia ZG. 2001. Defining Supply Chain Management. Journal of Business Logistics; 22(2): 125.

Pujawan, I.N. 2005. Supply Chain Management. Guna Widya, Surabaya.

Pujawan, I Nyoman. 2010. Supply Chain Management. Surabaya: Guna Widya.

Singarimbun, M., dan Effendi, S. 1989. Metode Penelitian Survai. Jakarta: LP3ES.

Usman, H., dan Akbar, R. P. S. 1995. Pengantar Statistika. Jakarta: Bumi Aksara.

Wibowo, R. 2007. Revitalisasi Komoditas Unggulan Perkebunan Jawa Timur. PERHEPI, Jakarta 